\title{
HUBUNGAN OBESITAS DENGAN HARGA DIRI (SELF-ESTEEM) PADA REMAJA PUTRI SMA NEGERI 13 SEMARANG
}

\author{
Priharyanti Wulandari 1), Arifianto 2), Nurul Aini 3) \\ 123Program Studi IImu Keperawatan STIKES Widya Husada Semarang \\ e-mail : wulancerank@yahoo.co.id
}

\begin{abstract}
Obesity is a major problem among teenages because it may causes low self esteem. The obesity rate were $32,9 \%$ and $29,05 \%$ in Indonesia and Central Java Province, respectively. The purpose of this study was to analyze the relationship beetween obesity and self esteem in young girl at Senior High school 13 SEMARANG. This was a correlational study. The sample size in this study was 85 young girls and the sampling method was stratified random sampling. The data were collected using a questionare and analyzed using spearman rank test. Result : The study results revealed that the majority of respondents were obese degree 1 whom most of them have positive self esteem 43 (79,6\%). In addition, 31 teenage were obesity grade II whom most of them have negative self esteem 26 girls $(83,9 \%)$. The statistical test result obtained using spearman rank test $\mathrm{P}$ value $=$ $0.000=0,05$. This study proved the relationship between teenage's obesity with self esteem. The respondents expected to lose weight by managing diet, doing exercise increasing self esteem, and viewing self positively.
\end{abstract}

Key words : Obesity, Self esteem, Teenage

\begin{abstract}
ABSTRAK
Obesitas suatu masalah yang cukup meresahkan di kalangan remaja putri karena memberikan dampak negatif secara psikologi menurunkan harga diri. Menurut RIKESDAS tahun 2013 di Indonesia mencapai 32,9\% dan di Jawa Tengah 29,0\%. Tujuan Penelitian ini adalah untuk menganalisis hubungan antara obesitas dengan harga diri pada remaja putri di SMA Negeri 13 Semarang. Penelitian ini menggunakan korelasi dengan pendekatan cross sectional. Jumlah sampel dalam penelitian ini adalah seluruh remaja putri yang obesitas di SMA Negeri 13 Semarang sebanyak 85 remaja putri, pengambilan sampel dengan menggunakan teknik Stratified random sampling. Instrumen yang digunakan adalah kuesioner menggunakan uji Spearman Rank. Hasil: Sebagian besar remaja (54 orang) mengalami obesitas derajat I dan mayoritas remaja tersebut memiliki harga diri positif (79.6\%). Jumlah remaja yang mengalami obesitas derajat II sebanyak 31 orang dan sebagian besar dari remaja tersebut harga diri negatif (83.9\%). Hasil uji statistik menggunakan uji Rank Spearman diperoleh nilai $\mathrm{P}_{\text {value }}=0.000 \leq \alpha=0,05(5 \%)$. Penelitian ini membuktikan adanya hubungan obesitas dengan harga diri (self-esteem) pada remaja putri, diharapkan responden menurunkan berat badan dengan memperbaiki asupan dan olahraga serta meningkatkan harga diri dan memiliki pandangan yang positif terhadap apa yang dimiliki.
\end{abstract}

Kata Kunci: Obesitas, Harga Diri, Remaja 


\section{PENDAHULUAN}

Masa remaja atau masa adolensens adalah masa peralihan dari masa kanak-kanak ke masa dewasa, yang meliputi semua perkembangan yang dialami sebagai persiapan memasuki masa dewasa (Kusmiran, 2013). Masa remaja dimulai antara usia 11 atau 12 tahun sampai dengan 20 tahun, menjelang masa dewasa muda dengan tahap-tahapan masa remaja yaitu: remaja awal/ dini (early adolescence) (10-13 tahun), remaja menengah (middle adolescence) (14-16 tahun), dan remaja akhir (lateadolescence) (17-19 tahun) (Soetjiningsih, 2007).

Masa remaja ditandai dengan pertumbuhan dan perubahan fisik salah satu perubahan fisik adalah berubahnya bentuk tubuh atau obesitas. Obesitas dianggap sebagai "momok" bagi seorang individu karena selain dapat berdampak langsung bagi kesehatan, juga sangat mengganggu penampilan fisik. Terlebih bagi para remaja yang memulai memikirkan penampilan fisik.

Masalah berat badan menjadi epidemi kesehatan terbesar di dunia, karena hampir 30 persen dari seluruh populasi kini mengalami obesitas, hal itu merupakan hasil studi baru yang dilakukan Christopher Murray Institute for Health Metrics and Evaluation (IHME) Universitas of Washington pada tahun 2013 dan diterbitkan dalam jurnal The Lancet. Penelitian ini menjadi analisis pertama berdasarkan tren data dari 188 negara di seluruh dunia. Kelebihan berat badan global selama tiga dekade terakhir melonjak signifikan dari 857 juta orang di tahun 1980 menjadi 2,1 miliar orang pada tahun 2013. Sepertiga dari mereka diklasifikasikan sebagai obesitas. Riset Institute for Health Metrics and Evaluation (IHME) yang dimuat dalam jurnal The Lancet menyebutkan dari 857 juta orang dengan obesitas tinggal di sepuluh negara berikut, Amerika Serikat, Cina, India, Rusia, Brasil, Meksiko, Mesir, Jerman, Pakistan, dan Indonesia menjadi 10 negara dengan penduduk yang mengalami kelebihan berat badan. Catatan Kementerian Kesehatan menyebutkan orang Indonesia yang kelebihan berat badan, sebagian diantaranya obesitas, mencapai angka 40 juta jiwa.

Riset Kesehatan Dasar (RIKESDAS) tahun 2013 di Indonesia menyebutkan bahwa prevalensi pada obesitas remaja (usia > 18 tahun) mencapai 32,9\%. Data Riset Kesehatan Dasar (RIKESDAS) pada tahun 2013 angka kejadian obesitas di Jawa Tengah (12,7\%), Yogyakarta $(22,2 \%)$, Jawa Barat $(18,9 \%)$ dan Jawa Timur $(20,3 \%)$. Prevalensi obesitas umum pada remaja usia $>18$ tahun menurut jenis kelamin, untuk perempuan di Provinsi Jawa Barat sebesar $(36,1 \%)$, Jawa Tengah $(29,0 \%)$, Yogyakarta $(31,5 \%)$, dan Jawa Timur $(35,1 \%)$. Prevalensi obesitas umum pada remaja usia> 18 tahun menurut jenis kelamin. (Badan Litbang Kesehatan 2013). Prevalensi kegemukan pada remaja $>18$ tahun di semua provinsi dari tahun 2007-2014 meningkat (19\%) (Badan Litbang Kesehatan 2013). Jawa Tengah merupakan provinsi dengan prevalensi tinggi dari setiap golongan umur remaja terdapat di Pulau Jawa.

Obesitas atau disebut juga kegemukan, merupakan suatu masalah yang cukup merisaukan dikalangan remaja. Obesitas terjadi saat badan menjadi gemuk yang disebabkan oleh penumpukan jaringan adipose secara berlebihan (Atikah, 2010). Obesitas mempunyai dampak jangka pendek 
Tabel 1 Klasifikasi Obesitas

\begin{tabular}{lc}
\hline \multicolumn{1}{c}{ Klasifikasi } & BMI $\left(\mathrm{Kg} / \mathrm{m}^{2}\right)$ \\
\hline $\begin{array}{l}\text { Obesitas I } \\
\text { (ringan) }\end{array}$ & $25-29,9$ \\
\hline $\begin{array}{l}\text { Obesitas II } \\
\text { (sedang) }\end{array}$ & $30-39,9$ \\
\hline $\begin{array}{l}\text { Obesitas III } \\
\text { (berat) }\end{array}$ & $>40$ \\
\hline
\end{tabular}

maupun jangka panjang terhadap kesehatan. Gangguan kesehatan yang sering menyertai kegemukan adalah penyakit degeneratif (Tirtawinata, 2012) : 1) Gangguan psikososial, rasa rendah diri, menarik diri dari lingkungan. 2) Penderita tekanan darah tinggi 10x lebih sering dialami orang yang mengalami kegemukan. 3) Hiperkolestrolemia menyertai penderita obesitas dan mengakibatkan aterosklerosis. 4) Penyakit jantung koroner disebabkan aterosklerosis yang menyumbat pembuluh nadi yang menyuplai darah ke dinding jantung. 5) Obesitas mengalami stroke karena aliran darah tersumbat karena arterosklerosis maka pembuluh darah akan menyempit sehingga terbendung dan mengakibatkan pembuluh darah pecah atau bocor. 6) Beban berat yang berlebihan mengakibatkan radang di persendian tulang. 7) Daya tahan tubuh orang yang obesitas menurun sehingga mudah sakit. Penghitungan Index Masa Tubuh (IMT) atau Body Mass Index (BMI) dapat membantu untuk mengidentifikasi remaja yang berisiko mengalami kelebihan berat badan. Rumus penghitungan IMT adalah sebagai berikut :

$I M T=\frac{\text { Berat Badan }(\mathrm{Kg})}{\text { Tinggi Badan }(\mathrm{m}) \times \text { Tinggi badan }(\mathrm{m})}$

Obesitas dapat mempengaruhi harga diri seseorang. Harga diri adalah penilaian pribadi terhadap hasil yang dicapai dengan menganalisis seberapa banyak kesesuaian tingkah laku dengan ideal dirinya (Suliswati, 2005). Harga diri (self-esteem) adalah penilaian tentang nilai individu dengan menganalisa kesesuaian perilaku dengan ideal diri (Fajariyah, 2012). Macam-macam harga diri : 1) Harga diri positif adalah sebuah kualitas pribadi yang dapat mengantarkan kita menuju penghargaan diri dan kesuksesan pribadi (Wita, 2011). 2) Harga diri negatif adalah perasaan tidak berharga, tidak berarti, dan rendah diri yang berkepanjangan akibat evaluasi negatif terhadap diri sendiri dan kemampuan diri (Yosep, 2011).

\section{METODE PENELITIAN}

Penelitian ini menggunakan jenis penelitian studi Korelasi (Notoatmodjo 2010). Populasi dalam penelitian ini adalah siswi kelas $\mathrm{X}$ dan kelas $\mathrm{XI}$ yang mengalami obesitas dan jumlah populasi penelitian 108 siswi. Sampel dalam penelitian ini adalah remaja putri dengan obesitas di SMA Negeri 13 Semarang sebanyak 85 orang yang direkrut menggunakan teknik Stratified random sampling.

\section{HASIL DAN PEMBAHASAN}

\section{Karakteristik Responden Umur Responden}

Tabel 2 Distribusi frekuensi berdasarkan umur

\begin{tabular}{cccc}
\hline Mean & Minimum & Maksimum & Std \\
\hline 16.96 & 15 & 18 & .879
\end{tabular}

Tabel 2 menunjukkan distribusi frekuensi remaja putri berdasarkan umur, diketahui bahwa rata - rata umur responden penelitian adalah 16,96 tahun. Umur 
termuda adalah 15 tahun dan umur tertua adalah 18 tahun.

\section{Kelas Responden}

Tabel 3 Distribusi frekuensi berdasarkan kelas

\begin{tabular}{lcc}
\hline Kelas & Frekuensi & $\%$ \\
\hline $\mathrm{X}$ & 38 & 44.7 \\
$\mathrm{XI}$ & 47 & 55.3 \\
\hline Total & 85 & 100.0
\end{tabular}

Tabel 3 menunjukkan distribusi frekuensi remaja putri berdasarkan kelompok kelas, diperoleh hasil kelas $\mathrm{X}$ sebanyak 38 orang $(44,7 \%)$ dan kelas XI sebanyak 47 orang $(55,3 \%)$.

\section{Keluarga yang Obesitas}

Tabel 4 Distribusi frekuensi berdasarkan keluarga yang obesitas

\begin{tabular}{lcc}
\hline $\begin{array}{l}\text { Keluarga Yang } \\
\text { Obesitas }\end{array}$ & Frekuensi & $\%$ \\
\hline Bapak & 25 & 29,4 \\
lbu & 31 & 36,5 \\
$\begin{array}{l}\text { Saudara } \\
\text { Sekandung }\end{array}$ & 10 & 11,8 \\
$\begin{array}{l}\text { Saudara } \\
\text { Kandung Dari }\end{array}$ & 9 & 10,6 \\
$\begin{array}{l}\text { Ayah } \\
\text { Saudara } \\
\text { Kandung Dari } \\
\text { lbu }\end{array}$ & 3 & 3,5 \\
Kakek/Nenek & 7 & 8,2 \\
\hline Total & 85 & 100 \\
\hline
\end{tabular}

Tabel 4 menunjukkan distribusi frekuensi remaja putri berdasarkan keluarga yang obesitas. Didapatkan hasil bapak yang obesitas sebanyak 25 orang
$(29,4 \%)$, ibu yang obesitas sebanyak 31 orang $(36.5 \%)$, saudara kandung yang obesitas sebanyak 10 orang $(11,8 \%)$, saudara kandung dari ayah yang obesitas sebanyak 9 orang $(10,6 \%)$, saudara sekandung dari ibuyang obesitas sebanyak 3 orang $(3,5 \%)$, dan kakek/nenek yang obesitas sebanyak 7 orang $(8,2 \%)$.

\section{HASIL UNIVARIAT}

\section{Obesitas pada Remaja Putri}

Tabel 5 Distribusi frekuensi berdasarkan derajat obesitas pada remaja putri

\begin{tabular}{lcc}
\hline Obesitas & Frekuensi & $\%$ \\
\hline $\begin{array}{l}\text { Obesitas I } \\
\text { (Ringan) }\end{array}$ & 54 & 63,5 \\
$\begin{array}{l}\text { Obesitas II } \\
\text { (Sedang) }\end{array}$ & 31 & 36,5 \\
\hline Total & 85 & 100 \\
\hline \multicolumn{1}{r}{ Hasil } & penelitian & menunjukkan
\end{tabular}
sebagian besar remaja putri mengalami obesitas derajat I (ringan) 54 orang $(63,5 \%)$ dan sisanya mengalami obesitas derajat II (36,5\%).

Ciri utama pada masa remaja, ditandai dengan adanya berbagai perubahan yang terjadi pada remaja baik secara sikap, perilaku, psikologis, sosial dan fisik yang akan saling berpengaruh antara satu dengan lainnya. Perubahan fisik yang terjadi pada masa remaja adalah pertambahan tinggi badan dan berat badan yang pesat (Lestari \& Rahmawati, 2006). Perubahan fisik yang sangat signifikan pada remaja dapat menimbulkan dampak psikologis yang tidak diinginkan. Aspek psikologis salah satu dari perubahan fisik di masa pubertas adalah remaja menjadi sangat memperhatikan tubuh dibandingkan aspek lain. Penampilan fisik yang 
menarik sangat penting bagi remaja karena daya tarik fisik merupakan salah satu aspek yang dilihat dalam kesan pertama individu yang akan mempengaruhi dukungan sosial.

$\begin{array}{ccc} & \text { Remaja yang mengalami } \\ \text { obesitas hendaknya melakukan }\end{array}$ perubahan pola makan (diet) dan bila ada faktor genetik dalam obesitas maka harus memperhatikan pola makan sehari - hari dengan rendah kalori tinggi protein agar tidak obesitas serta hindari konsumsi junk food, meningkatkan aktifitas fisik dengan aerobik dengan memilih olahraga yang tidak menumpuk berat badan yang akan menyebabkan sakit didalam persendian dan kaki, renang bisa menjadi pilihan.

\section{Harga Diri pada Remaja Putri}

Tabel 6 Distribusi frekuensi berdasarkan Harga Diri pada Remaja Putri

\begin{tabular}{lcc}
\hline Kejadian Diare & Frekuensi & $\%$ \\
\hline Harga Diri Positif & 48 & 56.5 \\
Harga Diri Negatif & 37 & 43.5 \\
\hline Total & 85 & 100 \\
\hline
\end{tabular}

Hasil penelitian dari 85 remaja putri di SMA Negeri 13 Semarang, berdasarkandistribusi frekuensi remaja putriberdasarkan rentang harga diri, didapatkan hasil terbanyak yaitu 48 orang $(56.5 \%)$ remaja putri dengan harga diri positif. Harga diri penting untuk kehidupan kita baik kehidupan pribadi, pergaulan maupun dalam kehidupan keluarga.Penelitian Bray bahwa orang yang mengalami obesitas mempunyai dampak yang buruk terhadap kesehatan dan interaksi sosial.Hal yang dialami oleh remaja obesitas tersebut tidak sejalan dengan salah satu tugas perkembangan remaja yaitu membangun kemampuan sosial karena lingkup sosial remaja yang sangat luas (Lestari \& Rahmawati, 2006).

\section{HASIL BIVARIAT}

Berdasarkan hasil penelitian terhadap 85 responden, menunjukan bahwa distribusi frekuensi remaja putriberdasarkan hubungan obesitas dengan harga diri, didapatkan hasil remaja putri dengan obesitas derajat I (ringan) yang mengalami harga diri positif sebanyak 43 orang $(79.6 \%)$, dan remaja putri dengan obesitas derajat II (sedang) yang mengalami harga diri negatif sebanyak 26 orang $(83.9 \%)$ remaja putri.

Hasil analisis statistik dengan uji rank spearman yang bertujuan menguji hubungan antara obesitas dengan harga diri (self-esteem) pada remaja putri SMA Negeri 13 Semarang diperoleh nilai rho= 0.617 , nilai $\mathrm{P}_{\text {value }}=0.000$, didapatkan nilai $\mathrm{P}_{\text {value }}=0.000 \leq \alpha=0,05(5 \%)$ maka $\mathrm{Ho}$ ditolak dan $\mathrm{Ha}$ diterima sehingga dapat dikatakan bahwa ada hubungan obesitas dengan harga diri (self-esteem) pada remaja putri di SMA Negeri 13 Semarang.

Penelitian pada 113 anak dan remaja di El-salvadoran American menyebutkan bahwa tingginya $\mathrm{BMI}$ (Body Mass Index) berhubungan dengan ketidakpuasan tubuh, rendahnya selfesteem, dan usaha untuk mengurangi berat badan.Ketidakpuasan terhadap tubuh memiliki hubungan signifikan dengan self-esteem (Rahmania, 2012).

Paparan fakta diatas menunjukan betapa serius dampak yang mengancam remaja putri akibat obesitas.Guiney dan Furlong menyatakan bahwa pada remaja putri, ketidakpuasan terhadap tubuh berdampak pada harga diri yang lebih 
rendah dari pada remaja putri yang lain. Ketidakpuasan yang mendalam terhadap diri sendiri terutama meningkat menjadi kebenvian terhadap

tubuh, merupakan suatu ekspresi dari harga diri yang rendah. Elis menyatakan seseorang mampu memodifikasi keyakinan dengan berfikir positif cara ini cara mempengaruhi perasaan yang akan dimunculkan dalam situasi spesifik (Mukhlis, 2013) dapat menurunkan rasa percaya diri dan menyebabkan gangguan psikologi (Atikah, 2010). Belum lagi kemungkinan diskriminasi dari lingkungan luar, maka remaja akan tumbuh menjadi remaja yang kurang percaya diri (Depkes Poltekes, 2010). Dampak lain pada seseorang yang mengalami obesitas adalah ketidakmampuan menerima keadaan dirinya, ini dapat menyebabkan remaja merasa ada kekurangan didalam

Tabel 7 Hubungan Obesitas dengan Harga Diri (Self-Esteem) pada Remaja Putri

\begin{tabular}{|c|c|c|c|c|c|c|c|c|}
\hline \multirow{3}{*}{ Obesitas } & \multicolumn{6}{|c|}{ Harga Diri } & \multirow{3}{*}{ Rho } & \multirow{3}{*}{$P_{\text {value }}$} \\
\hline & \multicolumn{2}{|c|}{$\begin{array}{l}\text { Harga Diri } \\
\text { Positif }\end{array}$} & \multicolumn{2}{|c|}{$\begin{array}{l}\text { Harga Diri } \\
\text { Negatif }\end{array}$} & \multicolumn{2}{|c|}{ Total } & & \\
\hline & $f$ & $\%$ & $F$ & $\%$ & $f$ & $\%$ & & \\
\hline Obesitas I ringan & 43 & 79.6 & 11 & 20.4 & 54 & 100 & \multirow{3}{*}{0.617} & \multirow{3}{*}{0.000} \\
\hline \multirow[t]{2}{*}{ Obesitas II sedang } & 5 & 16.1 & 26 & 83.9 & 31 & 100 & & \\
\hline & 48 & 56.5 & 37 & 43.5 & 85 & 100 & & \\
\hline
\end{tabular}

Penelitian yang dilakukan oleh Nurdinah dkk (2014) di SMA Dharma Pancasila Kelurahan Selayang Kota Medan mengenai hubungan obesitas dengan harga diri pada remaja menunjukan bahwa sebagian besar responden berumur 17 tahun, memiliki harga diri tinggi dengan obesitas sebanyak $23.3 \%$, dan sebanyak $76,7 \%$ memiliki harga diri negatif dengan obesitas. Didapatkan hasil ada hubungan obesitas dengan harga diri pada remaja, dengan nilai $\mathrm{P}_{\text {value }}=0,004$ $\leq \alpha=0,05$. Sesuai dengan teori bahwa hal yang paling menonjol dalam tumbuh kembang remaja adalah perubahan fisik serta psikososial, perubahan fisik terjadi lebih cepat daripada proses psikososial hal ini yang menyebabkan remaja sensitif terlebih pada remaja putri (Kumalasari, 2013). Obesitas di kalangan remaja merupakan permasalahan yang meresahkan karena dirinya, karena merasa ada kekurangan maka menyebabkan remaja merasa minder dalam pergaulan mereka akan menarik diri dalam kelompok.

\section{Kesimpulan}

1. Sebagian besar derajat obesitas pada remaja di SMA N 13 Semarang adalah obesitas derajat I.

2. Ada hubungan bermakna antara obesitas dengan harga diri rendah pada remaja di SMA N 13 Semarang.

\section{Saran}

1. Bagi Masyarakat

Diharapkan remaja untuk selalu mengatur pola makan, melakukan olah raga agar tidak terjadi obesitas dan mencegah harga diri rendah pada remaja yang obesitas.

2. Bagi Perawat Komunitas

Diharapkan tenaga kesehatan mampu memberikan pengetahuan tentang upaya pencegahan dan 
penanganan obesitas dan memberi pengetahuan tentang upaya pencegahan dan penanganan obesitas. Selain itu perawat juga memberikan perhatian terhadap remaja yang obesitas dan mengalami harga diri rendah.

3. Bagi Peneliti Selanjutnya

Diharapkan dapat lebih mengembangkan penelitian tentang intervensi untuk meningkatkan harga diri pada remaja yang mengalami harga diri rendah akibat obesitas.

\section{DAFTAR PUSTAKA}

Alimul. 2003. Metode Penelitian Keperawatan Dan Teknik Analisis Data. Jakarta : Salemba.

Ali. 2006. Psikologi Remaja. Hal 9.Jakarta : PT.Bumi Aksara http://digilib.uinsby.ac.id/583/3/Ba b\%201.pdf

Arikunto, S. 2010. Prosedur Penelitian Suatu

Pendekatan Praktek.Jakarta : Rineka Cipta.

Budiarto, E. 2002. Biostatistika Untuk Kedokteran Dan Kesehatan Masyarakat. Jakarta: EGC.

Elfiana. 2009. Hubungan Obesitas dengan Konsep diri Remaja, http://respository.unad.ac.id/id/epri $n t / 5686$, diakses 3 Mei 2015, 9.25 pm

Fajariyah. 2012. Asuhan Keperawatan Dengan Gangguan Harga Diri Rendah. Jakarta: Trans Invo Media

Ghufron, R. 2010. Teori Teori Psikologi. Yogyakarta; Ar.Rezza Medika https://www.google.com/search?q =badan+pusat+statistik+hubungan +antara+harga+diri+dengan+perila ku+anoreksia+pada+remaja\&spell
$=1 \& e i=3 F A b V Z X N D t C W u A S B 70 H$ OAw, diakses 15 Mei 2015.

Gita. 2008. Hubungan Harga Diri dan Citra Tubuh pada Remaja Putri yang Mengalami Obesitas dari Sosek Menengah Atas. Vol 2 ; 10-

11,http://www.google.co.id/search ?q=harga+diri+positif+adalah\&ie= UTF8\&prmd=ivns\&ei=GxfVZzsC5 DjuQSDlqioDA\&atart $=10 \& s a=N$, $06.12 \mathrm{am}$

Jpnn (Jawa Pos) .2014, https://www.google.com/search?q =prevalensi+obesitas+indonesiat 2014\&ie=utf-8\&oe=utf-8, 3 Mei 2015, $2.59 \mathrm{am}$.

Kinanti. 2010. Gambaran Citra Tubuh pada Remaja yang Obesitas.http://repository.usu.ac.i d/bitstream/123456789/14505/1/1 OE00246.pdf, diakses 13 April 2015.

Kumalasari. 2013. Kesehatan Reproduksi untuk Mahasiswa Kebidanan dan Keperawatan.Jakarta : Salemba Medika

Kusmiran. 2013. Kesehatan Reproduksi Remaja dan Wanita.Jakarta : Salemba Medika

Lestari \& Rahmawati.2012. Hubungan Penerimaan Diri Dengan Kompetensi Sosial Pada Remaja Putri.Sumatrahttp://fbsi.mercubua na-yogyakarta.ac.id/wpcontent/uploads/2012/06/DeviLestari-Ade-Rahmawati-Remaja Obesitas.pk_.pdf.

Mukhlis.2013. Berfikir Positif Pada ketidakpuasan Terhadap Citra Tubuh. Jurnal Psikoislamika Vol 10 : $1 . \quad$ Malang. http://psikologi.uinmalang.ac.id/wpcontent/uploads/2 014/03/1-BERFIKIR-POSITIF- 
PADA-KETIDAKPUASAN-CITRATUBUH-Ahmad-Mukhlis.Pdf.

Nasir, dkk. 2011. Buku Ajar Metodologi Penelitian Kesehatan : Konsep Pembuatan Karya Tulis Dan Thesis Untuk Mahasiswa Kesehatan. Yogyakarta : Muha Medika.

Notoatmojo, Soekidjo.2010. Metodelogi Penelitian Kesehatan. Jakarta : PT. Rineka Cipta.

Nurdin. 2011. Tumbuh kembang Prilaku Manusia. Jakarta : EGC.

Papalia, F. 2014. Menyelami Perkembangan manusia. Jakarta Selatan : Salemba Humanika

Poltekes Depkes :Kesehatan Remaja Problem dan Solusinya . Salemba Medika .

Prameswati, M. 2013, Hubungan Obesitas dengan Citra Diri dan HDR pada Remaja Putri .Vol 1; $52-$

61,http://jurnal.unimus.ac.id/index .php/JKK/article/view/925/977, 3 Mei 2015, 8.43 pm.

Rahmania. 2012. Hubungan antara Self Esteem dengan Kecenderungan body Dysmorphic Disorder Pada Remaja Putri. Vol 1 : 2 http://journal.unair.ac.id/filerPDF/1 10810014 9v.pdf.

Rahmawati.2009. Aktifitas Fisik dan Diet pada Anak, http://lib.ui.ac.id/file?file=digital/12 6590-S-5633-Aktifitas\%20fisikHA.pdf, 3 Mei 2015, 8.45

Siska.2010. Penyesuaian Diri Pada Remaja Obesitas ditinjau Dari Kematangan Emosi dan Jenis Kelamin.Vol 1 no 2. Semarang.http://www.unaki.ac.id/ ejournal/index.php/jurnalinformatika/article/download/39/3 8.
Soetjiningsih. 2007. Tumbuh Kembang Remaja Dan Permasalahannya. Jakarta: Sagung Seto.

Sugiyono. 2007. Statistika Untuk Penelitian. Bandung : Alfabeta.

Suiaraoka.2012. Penyakit Degeneratif Faktor Resiko 9 Penyakit Degeneratif. Yogyakarta : Nuha Medika

Sulistiyo, 2013. Konsep Dan Keperawatan Nyeri. Yogyakarta : Ar-ruzz.

Setiawan, S.D. 2013. Buku Ajar : Statistik Kesehatan. Yogyakarta : Nuha Medika.

Tirtawinata. 2012. Ingin Menjadi Langsing Penanggulangan Obesitas Secara Terpadu . Jakarta; Fakultas Kedokteran Universitas Indonesia .

Wahyuni.2013. Hubungan Konsumsi Fast Foot Dengan Obesitas Pada Remaja.Aceh. http://simtakp.uui.ac.id/docjurnal/ SRI_WAHYUNI-jurnal.pdf

Wawan \& Dewi M. 2010.Pengetahuan, Sikap Dan Perilaku Manusia. Yogyakarta : Nuha Medika

Wijayanti. 2013. Analisis Faktor Penyebab Obesitas Dan Cara Mengatasi Obesitas Pada Remaja putri. Semarang.http://lib.unnes.ac.id/1 8887/1/6250408055.pdf

Yatim. 2010. Kendalikan Obesitas dan Diabetes Mengatur Pola Hidup dan Pola Makan . Jakarta: Indocamp.

Yosep. 2011. Keperawatan Jiwa (Edisi Revisi) . Bandung: Refika Aditama.

Yundarini, N.M.C., Sawitri, N.K.A., Utami, P.A.S , 2015 . Hubungan antara Citra Tubuh dengan Perilaku Makan pada Remaja Putri 
Jurnal Keperawatan Soedirman (The Soedirman Journal of Nursing), Volume 11, No. 2, Juli 2016)

https://www.google.com/search?q =penelitian+di+inggris+menyebut kan+bahwa+wanita+ingin+menja $\underline{\text { di+lebih+kurus+dari+pada+keada }}$ an+mereka+saat+ini+\%28Grogan
$\% 2 C+2008 \% 29+$ dilakukan+oleh+ siapa+tahun+berapa\&ie=utf8\&oe=utf-, diakses 3 April 2015, 9. 